\title{
ГЕЛЬ-ХРОМАТОГРАФИЯ ДИКАРБОНОВЫХ КИСЛОТ И ИХ ДИМЕТИЛОВЫХ ЭФИРОВ С НОРМАЛЬНОЙ И РАЗВЕТВЛЕННОЙ ЦЕПЬЮ
}

Tiina LINNAS, O. KIRRET. NORMAALSE JA HARGNENUD AHELAGA DIKARBOKSUOLHAPETE JA NENDE DIMETOULESTRITE GEELKROMATOGRAAFIA

Tiina LINNAS, O. KIRRET. GEL-CHROMATOGRAPHY OF LINEAR AND BRANCHED CHAIN DICARBOXYLIC ACIDS AND DIMETHYL ESTERS OF DICARBOXYLIC ACIDS

Адсорбционная хроматография на сефадексе G-25 и LH-20 была успешно применена для анализа и разделения бензойной кислоты от алифатических кислот ['] линейных и циклических мономеров в найлонах 66,6 и $610\left[{ }^{2}\right]$, а также для препаративного разделения различных изомеров пуринов $\left[{ }^{3}\right]$.

В данной работе сделана попытка разделить на геле LH-20 различные дикарбоновые кислоты и их эфиры, имеющие нормальную и разветвленную пепь.

\section{Экспериментальная часть}

Для гель-хроматографии использовалась установка, состоящая из колонны $(9,5 м \mu \times 2,0 \mu)$, сосуда элюента и фракционного коллектора OE-604 (скорость элюирования $16 \mathrm{mл/u}$ ). Для наполнителя колонны применяли сефадекс LH-20 (фирмы Pharmacia) в метаноле. Для определения $V$ (объем элюирования) и $V_{0}$ (свободный объем) в колонну вводили 1 мл пробы в 1 мл метанола. Оптическую плотность $\left(D_{\text {опт. }}\right)$ фракции определяли в диапазоне 230 м на УФ-спектрофотометре (SPEKTROMOM 201).

Разделение диметиловых эфиров дикарбоновых кислот на сефадексе LH-20

\begin{tabular}{|c|c|c|c|c|c|}
\hline \multirow{2}{*}{$\begin{array}{c}\text { Фракции } \\
\text { диметило- } \\
\text { вых эфиров } \\
\text { дикарбоно- } \\
\text { вых кислот }\end{array}$} & \multicolumn{2}{|c|}{ Состав смеси диэфиров, \% } & \multicolumn{2}{|c|}{ Объем элюирования $V, \mu л$} & \multirow{2}{*}{$\begin{array}{c}\text { Свободный } \\
\text { объем } V_{0}, \\
\text { мл }\end{array}$} \\
\hline & $\begin{array}{c}\text { Эфир с нор- } \\
\text { мальной } \\
\text { цепью }\end{array}$ & $\alpha$-метил & $\begin{array}{c}\text { Эфир с нор- } \\
\text { мальной } \\
\text { цепью }\end{array}$ & $\alpha$-метил & \\
\hline $\begin{array}{l}\mathrm{C}_{6} \\
\mathrm{C}_{7} \\
\mathrm{C}_{8}\end{array}$ & $\begin{array}{l}96,6 \\
96,0 \\
95,0\end{array}$ & $\begin{array}{l}3,4 \\
4,0 \\
5,0\end{array}$ & $\begin{array}{r}100,0 \\
97,0 \\
95,0\end{array}$ & $\begin{array}{r}107,0 \\
100,5 \\
99,5\end{array}$ & $\begin{array}{l}43,5 \\
43,5 \\
43,5\end{array}$ \\
\hline
\end{tabular}

Пр и ме ч а н ие. $\mathrm{C}_{6}-$ смесь диметиловых эфиров адипиновой и $\alpha$-метил адипиновой кислот; $\mathrm{C}_{7}-$ смесь диметиловых эфиров пимелиновой и $\alpha$-метил пимелиновой кислот; $\mathrm{C}_{8}-$ смесь диметиловых эфиров пробковой и $\alpha$-метнл пробковой кислот. 
Рис. 1. Хроматограмма чистых диметиловых эфиров $\mathrm{C}_{6}$ (диметиловый эфир адапиновой кислоты), $\mathrm{C}_{7}$ (диметиловый эфир пимелиновой кислоты), $\mathrm{C}_{8}$ (диметиловый эфир корковой кислоты).
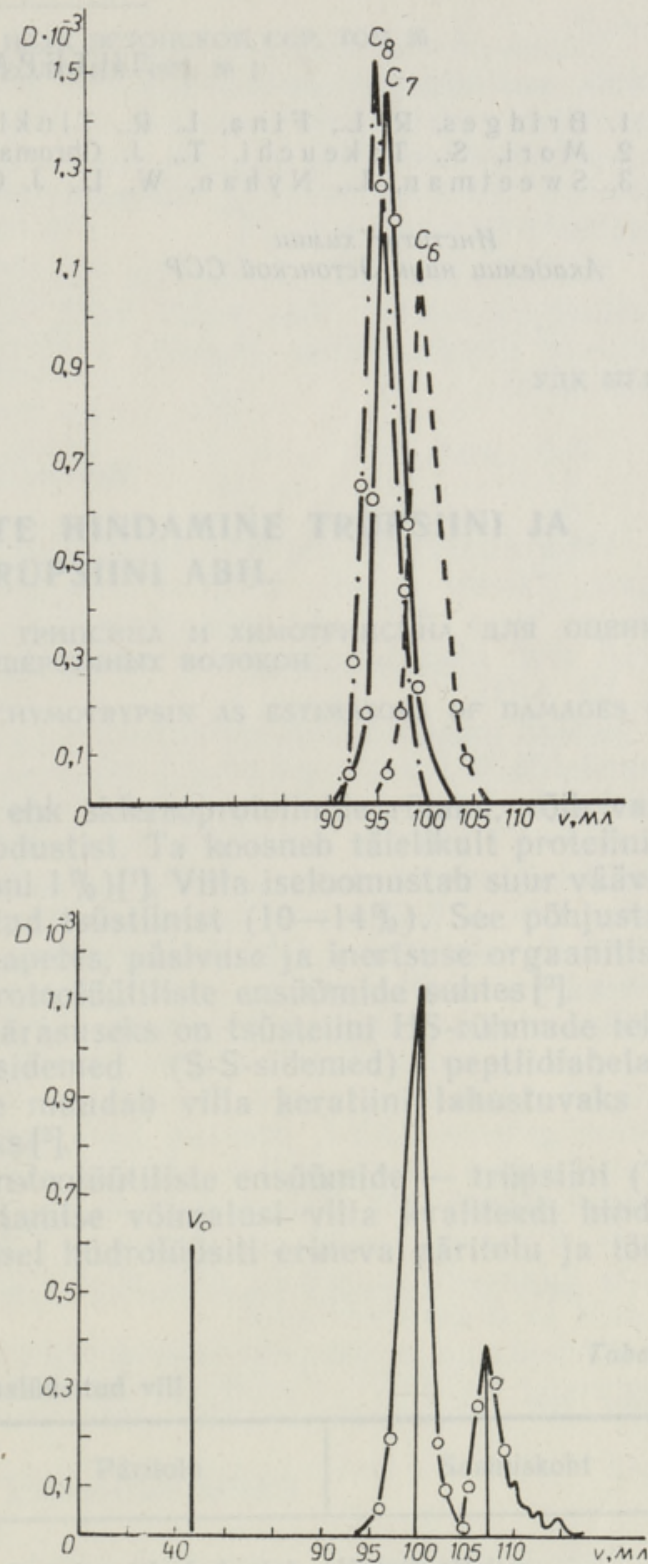

Рис. 2. Хроматограмма диметиловых эфиров фракции $\mathrm{C}_{6}$. Свободный объем $\left(V_{0}\right)$ определен с помощью поливинилового ацетата.

Эфиры дикарбоновых кислот с различной длиной цепи элюируются по общим правилам гель-фильтрации, т. е. эфиры с длинными цепями элюируются раньше (таблица), а разделение их по такой методике невозможно (рис. 1).

$\alpha$-Метилпроизводные эфиров дикарбоновых кислот элюируются позже эфиров с нормальной цепью (таблица), и эту методику в принципе можно применять для количественного разделения их (рис. 2).

На этой же колонне и в таком же порядке, как эфиры, были элюированы дикарбоновые кислоты $\mathrm{C}_{10}$ и $\mathrm{C}_{5}$, однако, поскольку их пики размываются, разделение на колонке с LH-20 невозможно. 


\section{Л И ТЕРА ТУ РА}

1. B ridges, R. L., Fin a, L. R., T i n k le r, S. L., J. Chromatogr., 39, 519 (1969).

2. Mori, S., Takeuchi, T., J. Chromatogr., 50, 419 (1970).

3. S w e et m a n, L., N y ha n, W. L., J. Chromatogr., 32, 662 (1968).

\section{Ннститут химии}

Академии наук Эстонской ССР
Поступила в редакцию $13 /$ XI 1975 